\title{
Coulisses
}

Revue de théâtre

13 | Hiver 1996

Varia

\section{Baptême du feu pour les nouveaux du TUFC à Montbéliard}

Françoise Chambefort

\section{OpenEdition}

1 Journals

Édition électronique

URL : http://journals.openedition.org/coulisses/4083

DOI : $10.4000 /$ coulisses.4083

ISSN : 2546-9460

Éditeur

Presses universitaires de Franche-Comté

\section{Édition imprimée}

Date de publication : 1 janvier 1996

Pagination : 49

ISSN : 1150-594X

\section{Référence électronique}

Françoise Chambefort, "Baptême du feu pour les nouveaux du TUFC à Montbéliard », Coulisses [En ligne], 13 | Hiver 1996, mis en ligne le 15 mars 2019, consulté le 04 octobre 2020. URL : http:// journals.openedition.org/coulisses/4083 ; DOI : https://doi.org/10.4000/coulisses.4083

Ce document a été généré automatiquement le 4 octobre 2020.

Coulisses 


\title{
Baptême du feu pour les nouveaux du TUFC à Montbéliard
}

\author{
Françoise Chambefort
}

1 Les participants à l'atelier du Théâtre Universitaire de Franche-Comté à Montbéliard, pour la plupart des novices dans l'art de l'intervention surprise, ont choisi de participer à leur manière aux journées consacrées à la lutte contre le SIDA. Dès 8 heures du matin, mercredi 29 Novembre, un préservatif géant traversait tranquillement la cour du campus à six mètres au-dessus du sol. Dépannage express pour une étudiante pressée qui réclamait à grand cri qu'on lui prête une « capote ». Le coup d'envoi était donné par une série d'interventions dans les salles de cours, derrière Marcel Djondo, portedrapeau du groupe, arborant fièrement des préservatifs multicolores fixés sur une corde à linge. Courir dans un couloir désert, s'arrêter devant une porte, entendre la voix du prof derrière cette porte, se regarder, chuchoter... Et quand Marcel rentre brutalement dans la classe en criant: « l'hiver s'annonce rude, il faut se couvrir!», le suivre, se mettre en place, JOUER. Et la grande découverte, ce fut le PLAISIR de jouer. À 18 heures, assis par terre en cercle dans la salle de cours où se déroule l'atelier, on fait le bilan. « On n'a même pas eu peur ! On s'est fait virer de l'amphi par un prof. En TP de biologie, certains regardaient plus leurs grenouilles que nos interventions... »

2 Il faudra apprendre à s'imposer davantage, pour être prêt à affronter toutes les situations. Car dans le théatre d'intervention, le public, c'est par la force qu'on le gagne. La force du jeu. 


\section{AUTEUR}

FRANÇOISE CHAMBEFORT

Bibliothécaire B.U. « Les portes du Jura » 